\title{
Pheromone study on acarid mites III Citral : isolation and identification from four species of acarid mites, and its possible role
}

\author{
Yasumasa KUwAhara, ${ }^{*, 1)}$ Hiroshi FUKAmI, ${ }^{*}$ Shojiro ISHII, ${ }^{*, 2}$ \\ Katsuhiko MATSUMOTO** and Yoshitake WADA** \\ * Pesticide Research Institute, College of Agriculture, \\ Kyoto University, Kyoto 606, Japan \\ ** Department of Parasitology, Tokyo Women's Medical \\ College, Shinjuku-ku, Tokyo 162, Japan
}

(Received: September 14, 1979)

\begin{abstract}
The alarm pheromone was isolated from Carpoglyphus lactis through the bioassay against the mold mite, Tyrophagus putrescentiae, and the compound was identified to be citral, ( $\mathrm{E}$ and Z)-3,7-dimethylocta-2,6-dienal. The occurence of citral in three other related species, Aleuroglyphus ovatus, Lardoglyphus konoi and Dermatophagoides farinae were also chromatographically demonstrated.
\end{abstract}

\section{INTRODUCTION}

Neryl formate, ( $\mathbf{z}$-3,7-dimethylocta-2,6-dien1-ol formate, was isolated from the mold mite, Tyrophagus putrescentiae (Schrank) and identified as an alarm pheromone (Kuwahara et al., 1975, 1979). The presence of the alarm pheromone has hitherto not reported in mites. It is well known that alarm pheromones, especially of social insects, are the least specific of pheromones and the same active compounds are shared in several taxonomically related species (Blum, 1969). In order to investigate the species-specificity of the mite's alarm pheromone, the crude pheromone extracts of the following five species

1) Present Address : Institute of Applied Biochemistry, The University of Tsukuba, Ibaraki 305, Japan

2) Professor Emeritus of Kyoto University

* 桑原保正 ${ }^{12}$, 深海 浩, 石井像二郎 ${ }^{22}$ : 京都大学 農学部付属農薬研究施設（干606 京都市左京区北 白川追分町)

**松本克彦, 和田芳武: 東京女子医科大学等华出学 教室（干162 東京都新宿区市谷河田町）

1) 現住所：筑波大学応用生物化学系（干305 茨城県 新治郡桜村天王台)

2) 現在：京都大学名誉教授 of mites were collected; Tyrophagus putrescentiae, Aleuroglyphus ovatus, Lardoglyphus konoi and Dermatophagoides farinae, and bioassayed against $T$. putrescentiae. Some alarm pheromone activites were detected in hexane extract of each species. In the present work the isolation and identification of the active principle ( $\mathrm{s}$ ) from the four species of mites were made and its possible role as the alarm pheromone was discussed.

\section{MAterials AND Methods}

Mite rearing: A. ovatus, fed on dry yeast (Matsumoto, 1965) and T.putrescentiae reared as reported (Kuwahara et al., 1975) and $C$. lactis fed on the mixture of dry yeast and sugar $(1: 1$, by weight $)$ were kept at $25^{\circ} \mathrm{C}$, $75 \% \mathrm{RH}$ in rearing vials, which were confined each in a desiccator with satd. $\mathrm{NaCl}$ solution (Matsumoto, 1965). Meanwhile L. konoi kept at $87 \% \mathrm{RH}$ in a desiccator with satd. $\mathrm{KCl}$ solution (Matsumoto, 1968), and D. farinae at $64 \% \mathrm{RH}$ with satd. $\mathrm{NH}_{4} \mathrm{NO}_{3}$ solution (Waki and Matsumoto, 1973) were both fed on the mixture of dry fish powder and dry yeast $(1: 1$, by weight).

All species of mites employed in the pre- 
sent study were maintained under abovementioned condition successively for years at the Department of Parasitology, The Tokyo Women's Medical College. These mites were separated periodically from culture medium by the saturated saline flotation method (Matsumoto, 1970) and stored at $-80^{\circ} \mathrm{C}$ before use.

Bioassay method: All bioassay were conducted as reported previously using $T$. putrescentiae (Kuwahara et al., 1979), unless otherwise mentioned.

Instrumentation: Gas-liquid chromatography was carried out by Yanako Model 550F, using three kinds of stainless steel columns; 1) $0.3 \mathrm{~cm}$ in diameter, $75 \mathrm{~cm}$ in length, packed with $15 \%$ PEG-20M on Chromosorb W, 60$80 \mathrm{mesh}$, at $100^{\circ} \mathrm{C}, 30 \mathrm{ml} / \mathrm{min}$ He flow rate, 2) $150 \mathrm{~cm}$ in length, packed with $5 \%$ DEGS on Chromosorb W, $60-80$ mesh, at $100^{\circ} \mathrm{C}$, $17 \mathrm{ml} / \mathrm{min}$, and 3) $75 \mathrm{~cm}$ in length, packed with Thermol $Q$ for terpenoid analysis (Shimadzu Seisakusho Ltd., Kyoto), 80-100 mesh, at $70^{\circ} \mathrm{C}, 30 \mathrm{ml} / \mathrm{min}$.

Mass spectrum was obtained by the combined gas chromatograph-mass spectrometer (Hitachi K-53-RMU-4) on glass column ( $3 \mathrm{~mm}$ id $\times 2 \mathrm{~m}$ in length) packed with $5 \%$ PEG-20M at $20 \mathrm{eV}$ and $120^{\circ} \mathrm{C}$.

\section{RESUlTS AND DISCUSSION}

With hexane all species of mites $(5-7 \mathrm{ml}$ by volume each) were soaked for several days and extracted separately. Small portions of aliquot of each extract was subjected to gasliquid chromatograph (PEG-20M at $100^{\circ} \mathrm{C}$ ), for surveying the presence of neryl formate, and also to bioassay.

Bioassay results indicated that extracts of four species of mites, $T$. putrescentiae, $C$. lactis, $D$. farinae and $L$. konoi showed the alarm pheromone activity against $T$. putrescentiae. Extracts of $A$. ovatus was found to be inactive at the tested concentration. Nevertheless the peak corresponding to neryl formate (tentatively named as peak 1) was detected in all species of mites as shown in Fig. 1. The height of peak 1 was measured in the chromatogram of each species (Table 1). It was noted that the bioassay results were not always parallel to the height of peak 1, which was accompanied with the

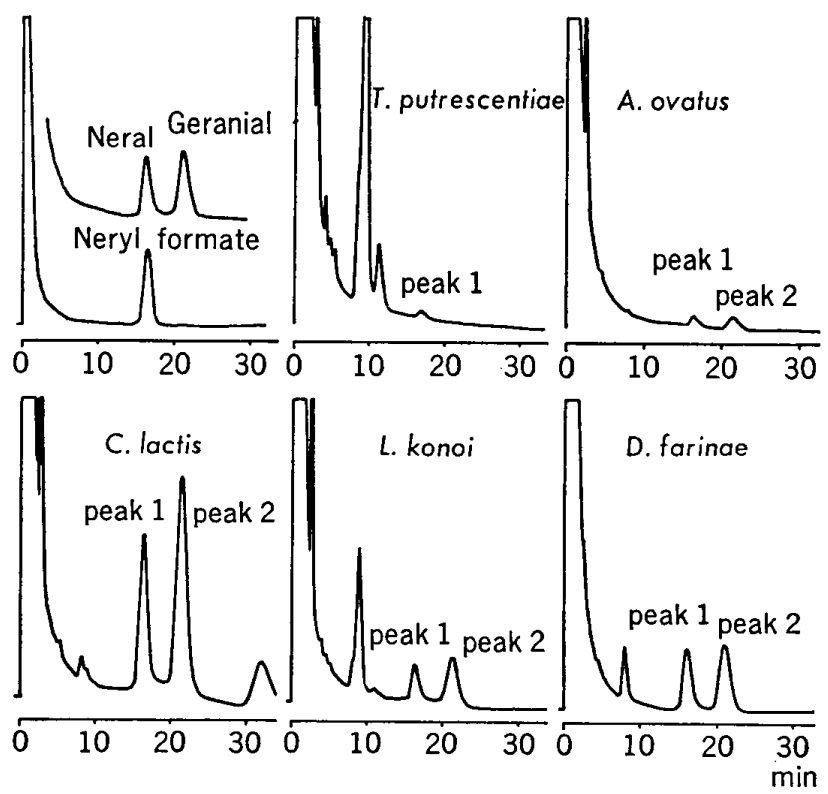

Fig. 1 Gas-liquid chromatograms of the crude extracts from all acarid mites employed (15\% PEG-20 M, $75 \mathrm{~cm}, 100^{\circ} \mathrm{C}$ ).

Table 1 GLC peak response of neryl formate from the crude extracts of mites and their alarm pheromone activity

\begin{tabular}{llcccc}
\hline \hline & \multicolumn{2}{l}{ Extracted volume } & $\begin{array}{l}\text { Peak height* } \\
\text { corresponding to } \\
\text { neryl formate }\end{array}$ & $\begin{array}{c}\text { Alarm pheromone } \\
\text { activity against } \\
\text { Tyrophagus }\end{array}$ \\
\hline Tyrophagus putrescentiae & $7.1 \mathrm{ml}$ & $7.8 \mathrm{ml}$ & $0.4 \mathrm{~cm}$ & + \\
hexane & 5.9 & 6.6 & 0.6 & $-*$ \\
Larroglyphus ovatus & 6.3 & 6.9 & 2.3 & + \\
Carpoglyphus lactis & 5.0 & 6.0 & 10.6 & + \\
Dermatophagoides farinae & 5.8 & 6.8 & 4.0 & + \\
\hline
\end{tabular}

* The same quantity of aliquot of the each extracts was subjected to GLC using a $15 \%$ PEG-20 M column at $100^{\circ} \mathrm{C}$.

** When the concentrated extract was assayed, positive response was observed. 
other peak (tentatively named as peak 2) except the case of $T$. putrescentiae. The peak 1 was noted to be smaller than the peak 2.

Each extract of mites was chromatographed on the silicic acid column $(5 \mathrm{~g}, 1.2 \mathrm{~cm}$ in diameter, $11 \mathrm{~cm}$ in height), eluted with $50 \mathrm{ml}$ each of pentane and a mixture of pentane and ether ( $20: 1$, by volume). After evaporation of the solvents, the resulted residue of both fractions from each species were filled up to $1 \mathrm{ml}$ with hexane, and analyzed by $\mathrm{GLC}$ at $100^{\circ} \mathrm{C}$ using a PEG-20M column. All peaks originally present in each extract were recovered separately in both fractions. It was noted that the fractions eluted with the mixture of pentane and ether consisted of two peaks (peak 1 and peak 2) in all species of mites except $T$. putrescentiae, and that the alarm pheromone activity was exclusively found in this fraction of all species except $A$. ovatus. From the quantity of peak 1 and the bioassay result of $A$. ovatus it is unlikely that peak 1 consist of neryl formate. In fact, further detailed analyses using two other GLC systems (5\% DEGS and Thermol Q) revealed that these two peaks were identical to citral, [ $z$ and E)-3,7-dimethylocta-2,6-dienal, or the mixture of neral and geranial], and neryl formate was different in their GLC retention times as shown in Table 2.

The active fraction of $C$. lactis was further purified with a silicic acid $(20 \mathrm{~g})$ column by eluting with benzene. Thus-purified and isolated active compounds were still a mix-

Table 2 Identification of non-hydrocarbon volatiles from four species of acarid mites except $T$. putrescentiac

$15 \%$ PEG-20M Thermol Q 5\% DEGS

\begin{tabular}{llcl}
\hline $\begin{array}{c}\text { Unknown } \\
\text { peak 1 }\end{array}$ & $14.4 \mathrm{~min}$ & $8.3 \mathrm{~min}$ & $6.8 \mathrm{~min}$ \\
$\begin{array}{c}\text { Unknown } \\
\text { peak 2 }\end{array}$ & 18.8 & 10.8 & 8.5 \\
$\begin{array}{l}\text { Neral* } \\
\text { Geranial* }\end{array}$ & 14.4 & 8.4 & 6.8 \\
$\begin{array}{c}\text { Neryl } \\
\text { formate }\end{array}$ & 14.8 & 10.8 & 8.5 \\
\hline
\end{tabular}

* The mixture of neral and geranial is called as "citral."

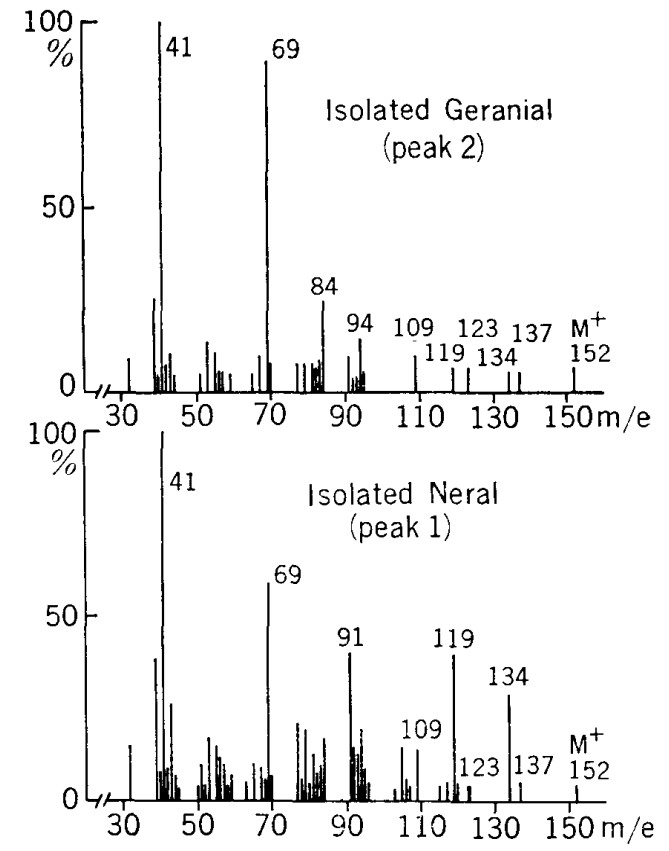

Fig. 2 Mass spectra of the isolated alarm pheromones from $C$. lactis against $T$. putrescentiae.

ture of the two peaks (yield; about $100 \mu \mathrm{g}$ in total, neral $40 \%$ and geranial $60 \%$, active at $100 \mathrm{ppm}$ ).

Mass spectra of these compounds were measured. Peak 1 and 2 gave the same molecular ion at $\mathrm{m} / \mathrm{e} 152$ and the same base ion peak at $\mathrm{m} / \mathrm{e} 41$ as shown in Fig. 2. The fragmentation pattern of peak 1 was identical to that of neral, and of the other peak 2 to that of geranial (Masada, 1975).

The commercially available citral (neral $35 \%$ and geranial $65 \%$ ) were bioassayed to give the alarm pheromone activty at $100 \mathrm{ppm}$ in hexane. This pheromonal activity was around one hundredth of neryl formate. From this result, it was understandable that extracts of L. konoi, C. lactis and D. farinae showed some alarm pheromone activity to $T$. putrescentiae. Presence of citral in $A$. ovatus was also supported from the following bioassay. When the bioassay was carried out with a filter paper impregnated with the concentrated extracts of $A$. ovatus, the filter paper distinctly showed the activity.

From the above-mentioned results, it was concluded that citral was contained in the following four species of mites, A. ovatus, $L$. konoi, C. lactis and $D$. farinae. No trace of neryl formate was found in these species, although their taxonomical status was very 
close to $T$. putrescentiae. It might be interesting to know the evolutional aspects of the alarm pheromone of mites in relation to their taxonomy.

In the preliminary experiment, both of $C$. lactis and $L$. konoi demonstrated the strong alarm pheromone activiy to citral and also to the squashed bodies of themselves or the filter papers impregnated with hexane extracts of themselves. This evidence supported that citral played a role of an alarm pheromone on at least these two species of mites. Possible role of citral on the other two species was not clear. However, from these facts that citral is anti-fungal substance (Cole et al., 1975, Okamoto et al., 1978), and that fungi never grow in a healthy culture of mites, the citral is supposed to function as one of the defence substances against fungi.

Detailed study on the role of citral present in mites and the biological activity against these species will be discussed elsewhere.

\section{ACKNOWLEDGEMENTS}

The authors wish to thank Dr. T. Ueno, Kyoto University, for measurement of GC-MS.

\section{REFERENCES}

Blum, S. M. (1969): Alarm pheromone. Ann. Rev. Entomol., $14: 57-80$.

Cole, L., M. Blum and R. Roncadori (1975) : Antifungal properties of the insect alarm pheromones, citral, 2-heptanone and 4-methyl-3heptanone. Mycologia, $67:$ 701-708.

Kuwahara, Y., S. Ishii and H. Fukami (1975): Neryl formate; alarm pheromone of the cheese mite, Tyrophagus putrescentiae (Schrank) (Acarina, Acaridae). Experientia, 31: 1115-1116.

Kuwahara, Y., H, Fukami, S. Ishii, K. Matsumoto and Y. Wada (1979): Pheromone study on acarid mites II. Presence of the alarm pheromone in the mold mite, Tyrophagus putrescentiae (Schrank) (Acarina: Acaridae) and the site of its production. Jap. J. Sanit. Zool., 30 : 309-314.

Masada, Y. (1975) : Analysis of Essential Oil by Gas Chromatography and Mass Spectrometry, pp. 276-277, Hirokawa Publishing Co., Inc., Tokyo.
Matsumoto, K. (1965) : Studies on environmental factors for breeding of grain mites VII. Relationship between reproduction of mites and kind of carbohydrates in the diet. Jap. J. Sanit. Zool., 16 : 118-122.

Matsumoto, K. (1968): Studies on environmental factors for breeding of grain mites IX. The effect of relative humidity on the age composition of the population of Lardoglyphus konoi. Jap. J. Sanit. Zool., 19 : 196-203.

Matsumoto, K. (1970) : Studies on environmental factors for breeding of grain mites X. Effect of temperature and relative humidity on the breeding and hypopus formation in Lardoglyphus konoi. Jap. J. Sanit. Zool., 21 : 213-219.

Okamoto, M., K. Matsumoto, Y. Wada and H. Nakano (1978): Studies on antifungal effect of mite alarm pheromone citral I. Evaluation of antifungal effect of citral. Jap. J. Sanit. Zool., 29 : 255-260.

Waki, S., and K. Matsumoto (1973): Studies on the environmental requirements for the breeding of the dust mite, Dermatophagoides farinae Hughes, 1961 Part I. Observation on the mode of breeding under various temperature and humidity conditions. Jap. J. Sanit. Zool., 23 : 159-163.

$$
\begin{gathered}
\text { 摘 要 } \\
\text { コナダニ類のフェロモン研究 III } \\
4 \text { 種のコナダニ類からのシトラールの } \\
\text { 単離と同定およびその役割 }
\end{gathered}
$$

ケナガコナダニ Tyrophagus putrescentiae の警報 フェロモンは蟻酸ネリルである。一般的に警報フェロモ ンは種特異的でないとされている. そこで近縁の 4 種の コナダニ類（サトウダニ, Carpoglyphus lactis, コオ ノホシカダニ, Lardoglyphus konoi, ムギコナダニ Aleuroglyphus ovatus, コナヒョウヒダニ, Dermatophagoides farinae) 粗抽出物のケナガコナダニに対す る活性を調べた， 4 種の粗抽出物（ムギコナダニは濃縮 すると）は活性を示した. ガスクロマトグラフ法分析 (GLC) の結果，4種の活性部は，ケナガコナダ二の場 合と異なり，2成分から成っていた，最も量の多いサ卜 ウダニ抽出物を精製し, 活性物䁲 $(100 \mu \mathrm{g})$ を単離した. 質量分析および GLC の結果から，シトラール（ネラー ル $40 \%$ ，ケラニアール $60 \%$ の混合物）上同定した.ケ ナガコナダニ以外のダニに儀酸ネリル注存在しない. 予備的な生物試験でサトウダニとコオノホシカダニはシ トラールに強い活性を示し，これらのダニではシトラー ルを䉒報フェロモンと推定した. 